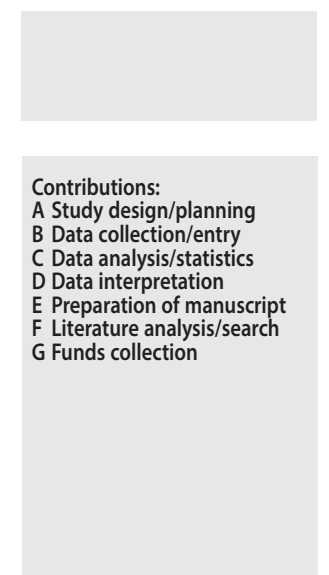

\section{AUDITORY ABILITIES IN INDIVIDUALS WITH AND WITHOUT FORMAL MUSICAL TRAINING}

\section{Cyntia Barbosa Luiz ${ }^{1, B, E}$, Nina Vazquez de Camargo, 3,2,A-G, Juliana Habiro de Souza Miguel ${ }^{3, D-F}$, Daniela Gil ${ }^{2, A, C-E}$}

${ }^{1}$ Department of Speech Therapy and Audiology, Universidade Federal de São Paulo, Brazil

${ }^{2}$ Fonoaudiologia, Universidade Federal de São Paulo, Brazil

${ }^{3}$ Departamento de Fonoaudiologia, Universidade Federal de São Paulo, Brazil

Corresponding author: Cyntia Barbosa Luiz; Department of Speech Therapy and Audiology, Universidade Federal de São Paulo, St. Botucatu, 802, 04023-062, São Paulo, Brazil; email: cyntialuiz@yahoo.com.br

\title{
Abstract
}

Introduction: Auditory perception can be enhanced by musical training and practice. Considering the multiple brain areas involved in musical learning, good auditory perceptual skills can contribute to phonological awareness, speech recognition in the presence of noise, reading, syllable recognition, and other language skills.

Material and methods: There were 30 adults between 18 and 27 years old who participated. They were divided into two groups: 15 individuals without formal musical training (Non-Musicians) and 15 individuals with 5 years or more of formal musical training (Musicians), paired by gender and age. Procedures used for assessing their hearing skills were the Duration Pattern test, Staggered Spondaic Word test, Masking Level Difference test, and Dichotic Consonant-Vowel test.

Results: In all tests, the Musicians group showed a higher average score than the Non-Musicians. In the MLD test, the average level difference was $3 \mathrm{~dB}$ higher for the Musicians than for the Non-Musicians $(p=0.001)$. There were also statistically significant mean differences between the groups for the DP test, SSW test in the right ear, and DCV test (number of errors).

Conclusions: Individuals with formal musical training show better auditory attention abilities, which are important for developing good listening skills, resulting in good communication and linguistic performance compared to individuals without prior musical training.

Key words: hearing tests $\bullet$ music $\bullet$ hearing $\bullet$ auditory perception $\bullet$ acoustic stimulation

\section{ZDOLNOŚCI SŁUCHOWE U OSÓB Z FORMALNYM WYKSZTAŁCENIEM MUZYCZNYM I BEZ TAKIEGO WYKSZTAŁCENIA}

\section{Streszczenie}

Wprowadzenie: Percepcja słuchowa może zostać usprawniona przez trening muzyczny i praktykę. Biorąc pod uwagę liczne obszary mózgu zaangażowane w naukę muzyki, wysokie kompetencje w zakresie percepcji słuchowej mogą pociągać za sobą większą świadomość fonologiczną, lepsze rozpoznawanie mowy w obecności szumu, czytanie, rozpoznawanie sylab i inne kompetencje językowe.

Materiał i metody: W badaniu uczestniczyło 30 dorosłych w wieku od 18 do 27 lat. Zostali podzieleni na dwie grupy: 15 osób bez formalnego wykształcenia muzycznego (Niemuzycy) i 15 osób, które miały pięcioletnie lub dłuższe formalne wykształcenie muzyczne (Muzycy), dobranych parami pod względem płci i wieku. Procedury użyte w celu oceny ich kompetencji słuchowych obejmowały: test sekwencji tonów o różnej długości (Duration Pattern, DP), test Staggered Spondaic Word (SSW), test Masking Level Difference (MLD) oraz test dychotyczny typu spółgłoska-samogłoska (Dichotic Consonant-Vowel, DCV).

Wyniki: We wszystkich testach grupa Muzycy uzyskała wyższe średnie wyniki niż Niemuzycy. W teście MLD średnia różnica poziomów była o $3 \mathrm{~dB}$ wyższa dla Muzyków niż dla Niemuzyków $(p=0,001)$. Zarejestrowano także statystycznie istotne średnie różnice pomiędzy dwiema grupami w teście DP, teście SSW w prawym uchu i teście DCV (liczba błędów).

Wnioski: Osoby z formalnym wykształceniem muzycznym wykazują większe kompetencje w zakresie uwagi słuchowej, ważne dla rozwoju dobrych kompetencji słuchowych, skutkujących lepszą komunikacją i osiągnięciami językowymi w porównaniu do osób nieposiadających wyszkolenia muzycznego.

Słowa kluczowe: testy słuchu $\bullet$ muzyka $\bullet$ słuch $\bullet$ percepcja słuchowa $\bullet$ stymulacja akustyczna

\section{Introduction}

Central Auditory Processing (CAP) is a set of processes and mechanisms of the central nervous system that enable decoding and understanding speech, especially in unfavorable situations, such as in the presence of background noise or competing messages [1]. The adequate development of this ability depends on factors such as preserved peripheral hearing, neurobiological maturation, environmental stimuli, and cognitive ability [2].

Assessment of central auditory processing aims at understanding auditory function and its relationship with communication, using behavioral auditory tests that aim to evaluate hearing performance in different listening tasks simulating daily life situations [3]. 
Central auditory abilities can be evaluated by auditory discrimination tests, binaural interaction, dichotic tasks, monaural low-redundancy, and temporal pattern tests. These abilities are involved in auditory processing and refer to the perception of auditory information by the central nervous system and the neurobiological activity underlying this perception [4].

Failure to perceive auditory information, or in the underlying neurophysiological processes, may affect the communication and cognitive performance of individuals with central auditory processing disorder (CAPD). As a consequence, it can also result in learning disorders and socioemotional issues. Therefore, one must use several tests to characterize central auditory function involving as many auditory abilities as possible.

Currently, music has been studied as to its brain modulation capacity and resulting functional changes, which can improve some cognitive aspects. Musical learning correlates with brain adaptations that can differentiate the performance of individuals with and without musical experience [5].

The first years of brain maturation are essential and formal musical training, initiated early in life, can result in structural adaptation, probably involving plastic reorganization (that is, changes in the synaptic connections and/or in the growth of neuronal extensions) [6]. The time dedicated to music exposure is also important, as significant changes in brain connectivity and functionality may occur [7].

Research conducted with the objective of relating musical to psychoacoustic abilities (in addition to those that address the relationship between music, language, cognition, and auditory processing), have given important data regarding the effect of music on an individual's cognitive development, especially in terms of memory and attention skills [8-11].

Learning a musical language involves using several brain areas simultaneously. These are perception, from the auditory pathways to processing in the upper regions of the brain; cognition, memory, attention, and executive functions; motor and auditory skills, as well as the ability to adapt to novel emerging stimuli, characterized by brain plasticity [12].

Musical practice develops with the auditory perception of melodies, harmonies, and rhythms via perceptual training of musical parameters. Considering the many brain activities involved in learning music, auditory perceptual skills can contribute to phonological awareness, speech recognition tasks in the presence of noise, reading, syllable recognition, and other language skills [13-16].

Thus, musical practice is an activity that can also improve speech recognition skills in noisy environments. Speech perception in noisy environment provides information on auditory function under limited conditions, since it requires integrating cognitive, linguistic, and sensory processing systems in response to sound input [17-20].

Based on the above, this study aims to characterize the auditory abilities of figure-ground and temporal ordering in adults with and without formal musical training.

\section{Methods}

This project was submitted to the Research Ethics Committee with approval number 2,317,345. All participants received information on each of the procedures performed in the research and signed an informed consent form. Adults between 18 and 27 years old, with auditory thresholds within the normal range of 0.25 and $8 \mathrm{kHz}$ (equal to or less than $25 \mathrm{~dB} \mathrm{HL}$ ) and type A tympanograms, participated in the study. Subjects were matched in terms of age and school level. There were 12 subjects who had college degrees and 18 were college students.

The sample consisted of two groups, divided according to musical experience and matched by gender and age: the first group consisted of 15 adults without musical experience and without complaints regarding language, while the second group consisted of 15 adults with at least 5 years of formal musical training who played any musical instrument except percussion. Both groups were recruited by in-person invitation from one of the project researchers who had contact with musicians from studios and music schools. The participants' formal musical training time ranged from 5 to 14 years, with an average of 8.7 years.

The Masking Level Difference test (MLD), Staggered Spondaic Word test (SSW), Dichotic Consonant-Vowel test - free recall (DCV), and Duration Pattern test (DP) were used to evaluate auditory processing. The tests were undertaken in 1-hour sessions with the participant inside an acoustic booth and using earphones.

MLD is a test that involves auditory binaural interaction. It determines the threshold to a $500 \mathrm{~Hz}$ pure pulsed tone in the presence of white noise under two conditions: noise and a pure tone in phase in both ears (homophasic) and in the other, a pure tone in phase in both ears and inverted phase noise in one of the ears (antiphasic) [21]. Participants were instructed to answer "yes" when they heard the tone (pulsed tone) and the noise, even if at low intensity and "no" when they heard only the noise [22]. To determine MLD, we subtracted the threshold obtained in the antiphasic condition from the threshold in the homophasic condition. Thresholds greater than $10 \mathrm{~dB}$ were considered within the standard criterion [23].

SSW is a dichotic test involving the auditory figure-ground ability for words and temporal ordering and the physiological mechanisms of selective attention and temporal processing. Each participant had to repeat the four words presented, maintaining their order of presentation [24]. First, the results underwent a quantitative analysis, considering the correct answers in the competitive conditions, regardless of ear. For adults or children over 9 years of age, the answers to the conditions Competitive Right and Competitive Left are expected to be greater than or equal to $90 \%$ of correct answers [25].

The DCV test evaluates the auditory figure-ground ability for syllables and the physiological mechanism of verbal sound recognition in a dichotic task. The study used only the free recall condition, in which the participant listened to a list with 24 pairs of syllables and was instructed to randomly choose one syllable to repeat. Norms for adults 
are to reach at least 19 correct responses with right ear advantage and 5 errors at maximum. For those who are left-handed, the number of correct answers in the left ear may be higher than in the right [26].

The DP test assesses auditory temporal ordering and the physiological mechanism of temporal processing. In this procedure, the participants listened to three-tone sequences based on long (L, $500 \mathrm{~ms}$ ) and short (S, $250 \mathrm{~ms}$ ) tones in six combinations - LLS, LSL, LSS, SLL, SLS, and SSL - and were then asked to name the sequence heard. For adults or children over 12 years of age, the standard criterion for this type of response is at least $83 \%$ correct answers [27].

Statistical analysis used Student's t-test or the Equality Test of two means - when it is assumed that population variance is known, independent, and normal - to compare the groups regarding age and performance in the tests. The qualitative analysis of the SSW test employed a Chi-squared test, which verifies whether two variables have a statistical dependence (association) or not. Pearson's correlation was used to measure how much one variable was related to the other; it was used to correlate the time of formal musical training and the test results.

We used statistical confidence intervals of $95 \%$ and considered a significance level of $0.05 \%$.

\section{Results}

Table 1 shows the quantitative results of the MLD test for both groups. Here, there is a statistically significant difference between the groups, with the mean in decibels being nearly $3 \mathrm{~dB}$ higher for the Musicians than for the Non-musicians.
Table 2 shows descriptive measures of group performance for the DP, SSW, and DCV tests, in percentage of correct answers. There was a statistically significant mean difference between the groups for the DPT, SSW-RE, and DCVErrors tests. We observed that in all tests the Musicians presented a higher average of correct answers compared to the Non-musicians (except of course for the variable DCVErrors, which is an inverse measure - that is, less mistakes made by the musicians).

Table 3 shows the data of the qualitative analysis of the procedures applied in each group. There is a statistical significance between the groups for the distribution in the results of the MLD, SSW, and DCV tests. In these three procedures there was a higher percentage of "normal results" for the musicians than for non-musicians.

Table 4 shows the correlations between the extent of formal musical training and the results of the tests evaluating auditory processing. Here there is no statistically significant correlation.

\section{Discussion}

For the Masking Level Difference (MLD) test (Table 1), we observed that the Musicians group had a higher average than the Non-musicians group. The test involves auditory binaural integration and, as described in the literature, studies with MLD in children have shown that the peripheral and brainstem auditory processes responsible for MLD are completely formed by the sixth month of life $[28,29]$.

The Musicians group had a mean MLD response of $10.3 \mathrm{~dB}$, which shows that they had good binaural integration, significantly better than the Non-musicians, which had a mean

Table 1. Descriptive measures of group performance in terms of Masking Level Difference (MLD in dB)

\begin{tabular}{|c|c|c|c|c|c|c|c|c|c|c|}
\hline Groups & & Mean & Median & $\begin{array}{l}\text { Standard } \\
\text { deviation }\end{array}$ & CV & Min & Max & $\mathbf{N}$ & $\mathbf{C l}$ & $p$-value \\
\hline \multirow{2}{*}{ MLD } & Musicians & 10.27 & 10 & 1.67 & $16 \%$ & 6 & 12 & 15 & 0.84 & \multirow{2}{*}{0.001} \\
\hline & Non-musicians & 7.33 & 6 & 2.69 & $37 \%$ & 4 & 12 & 15 & 1.36 & \\
\hline
\end{tabular}

Key: CV - Coefficient of Variation; Cl - Confidence Interval

Table 2. Descriptive measures of group performance in the DP, SSW, and DCV tests (percentage of correct answers)

\begin{tabular}{|c|c|c|c|c|c|c|c|c|c|c|}
\hline Groups & & Mean & Median & $\begin{array}{l}\text { Standard } \\
\text { deviation }\end{array}$ & CV & Min & Max & $\mathbf{N}$ & $\mathrm{Cl}$ & $p$-value \\
\hline \multirow{2}{*}{ DP } & Musicians & $98.9 \%$ & $100 \%$ & $2.0 \%$ & $2 \%$ & $93 \%$ & $100 \%$ & 15 & $1.0 \%$ & \multirow{2}{*}{0.001} \\
\hline & Non-musicians & $93.4 \%$ & $93 \%$ & $5.6 \%$ & $6 \%$ & $80 \%$ & $100 \%$ & 15 & $2.8 \%$ & \\
\hline \multirow{2}{*}{ SSW-RE } & Musicians & $98.3 \%$ & $100 \%$ & $2.2 \%$ & $2 \%$ & $93 \%$ & $100 \%$ & 15 & $1.1 \%$ & \multirow{2}{*}{0.008} \\
\hline & Non-musicians & $94.8 \%$ & $95 \%$ & $4.2 \%$ & $4 \%$ & $88 \%$ & $100 \%$ & 15 & $2.1 \%$ & \\
\hline \multirow{2}{*}{ SSW-LE } & Musicians & $96.3 \%$ & $98 \%$ & $3.5 \%$ & $4 \%$ & $90 \%$ & $100 \%$ & 15 & $1.8 \%$ & \multirow{2}{*}{0.135} \\
\hline & Non-musicians & $94.0 \%$ & $93 \%$ & $4.7 \%$ & $5 \%$ & $88 \%$ & $100 \%$ & 15 & $2.4 \%$ & \\
\hline \multirow{2}{*}{ DCV-RE } & Musicians & $50.0 \%$ & $54 \%$ & $13.3 \%$ & $27 \%$ & $25 \%$ & $67 \%$ & 15 & $6.7 \%$ & \multirow{2}{*}{0.414} \\
\hline & Non-musicians & $46.6 \%$ & $46 \%$ & $8.2 \%$ & $18 \%$ & $33 \%$ & $63 \%$ & 15 & $4.2 \%$ & \\
\hline \multirow{2}{*}{ DCV-LE } & Musicians & $35.3 \%$ & $33 \%$ & $8.9 \%$ & $25 \%$ & $25 \%$ & $50 \%$ & 15 & $4.5 \%$ & \multirow{2}{*}{0.123} \\
\hline & Non-musicians & $29.7 \%$ & $25 \%$ & $10.3 \%$ & $35 \%$ & $17 \%$ & $50 \%$ & 15 & $5.2 \%$ & \\
\hline \multirow{2}{*}{ DCV-Errors } & Musicians & $14.7 \%$ & $17 \%$ & $6.1 \%$ & $41 \%$ & $8 \%$ & $29 \%$ & 15 & $3.1 \%$ & \multirow{2}{*}{0.001} \\
\hline & Non-musicians & $23.6 \%$ & $25 \%$ & $6.4 \%$ & $27 \%$ & $13 \%$ & $33 \%$ & 15 & $3.3 \%$ & \\
\hline
\end{tabular}

Key: CV - Coefficient of Variation; Cl - Confidence Interval; DP - Duration Pattern test; SSW - Staggered Spondaic Word test;

DCV - Dichotic Consonant-Vowel test; RE - right ear, LE - left ear 
Table 3. Results of tests according to group (musicians vs non-musicians)

\begin{tabular}{|c|c|c|c|c|c|c|c|c|}
\hline & & \multicolumn{2}{|c|}{ Musicians } & \multicolumn{2}{|c|}{ Non-musicians } & \multicolumn{2}{|c|}{ Total } & \multirow{2}{*}{ p-value } \\
\hline & & $N$ & $\%$ & $\mathbf{N}$ & $\%$ & $\mathbf{N}$ & $\%$ & \\
\hline \multirow{2}{*}{ MLD } & Altered & 2 & $13.3 \%$ & 11 & $73.3 \%$ & 13 & $43.3 \%$ & \multirow{2}{*}{0.001} \\
\hline & Normal & 13 & $86.7 \%$ & 4 & $26.7 \%$ & 17 & $56.7 \%$ & \\
\hline \multirow{2}{*}{ SSW } & Altered & 0 & $0.0 \%$ & 5 & $33.3 \%$ & 5 & $16.7 \%$ & \multirow{2}{*}{0.014} \\
\hline & Normal & 15 & $100.0 \%$ & 10 & $66.7 \%$ & 25 & $83.3 \%$ & \\
\hline \multirow{2}{*}{ DCV } & Altered & 3 & $20.0 \%$ & 10 & $66.7 \%$ & 13 & $43.3 \%$ & \multirow{2}{*}{0.010} \\
\hline & Normal & 12 & $80.0 \%$ & 5 & $33.3 \%$ & 17 & $56.7 \%$ & \\
\hline \multirow{2}{*}{ DP } & Altered & 0 & $0.0 \%$ & 2 & $13.3 \%$ & 2 & $6.7 \%$ & \multirow{2}{*}{0.143} \\
\hline & Normal & 15 & $100.0 \%$ & 13 & $86.7 \%$ & 28 & $93.3 \%$ & \\
\hline
\end{tabular}

Key: MLD - Masking Level Difference test; DP - Duration Pattern test; SSW - Staggered Spondaic Word test; DCV - Dichotic Consonant-Vowel test

Table 4. Correlations between years of formal musical training and test results

\begin{tabular}{lcc}
\hline & Corr $(\boldsymbol{r})$ & p-value \\
\hline MLD & $-3.7 \%$ & 0.896 \\
\hline DP & $22.8 \%$ & 0.415 \\
\hline SSW-RE & $-32.0 \%$ & 0.245 \\
\hline SSW-LE & $10.7 \%$ & 0.705 \\
\hline DCV-RE & $-15.8 \%$ & 0.574 \\
\hline DCV-LE & $22.6 \%$ & 0.418 \\
\hline DCV-errors & $1.9 \%$ & 0.948 \\
\hline
\end{tabular}

Key: Corr - correlation; MLD - Masking Level Difference test; DP - Duration Pattern test; SSW - Staggered Spondaic Word test; DCVT - Dichotic Consonant-Vowel test, RE - right ear, LE - left ear

MLD of $7.3 \mathrm{~dB}$. Binaural integration helps in identifying a sound source and gives better temporal auditory perception. The brainstem is responsible for detecting time and intensity differences between the ears, which contributes to improve speech recognition in the presence of competing noise [17,30-32].

Table 2 shows that the Musicians group had a higher average of correct answers compared to the Non-musicians in the DP test; SSW test, and DCV test; of course, with the DCV-Errors variable the number was lower.

Musicians had better performance for the figure-ground and temporal ordering skills, revealing better capacity for selective attention and temporal processing in this group [18]. In the literature, some studies have already shown the better performance of musicians in these abilities $[5,7-9,18]$. Musicians have better frequency discrimination and ordering than non-musicians, and other authors have concluded that musical training promotes speech processing plasticity, resulting in better ability to understand speech in noise, which relates to selective attention capacity. Musicians also have better auditory temporal ordering, suggesting that their training and musical experience improves this performance.

Table 2 shows an advantage for the right ear in both groups in the DCV test. Such an advantage is related to the neurophysiological model of dichotic listening, in which information received by the right ear is processed in the left hemisphere and is often more quickly analyzed and organized than information received by the left ear. This is because the left hemisphere contains most of the structures involved in perceiving speech acoustic cues (frequency, intensity, and duration) $[6,11,32]$.

Musicians had a lower amount of errors in the DCV test than the non-musicians (Table 2), indicating better phonemic discrimination of similar sounds by musicians, since the test stimuli involves pairs of syllables that differ only by the sound of the consonant $[8,9,11]$.

The Musicians group had a higher percentage of responses within the normal range for the MLD, SSW, and DCV tests than the Non-musicians (Table 3). Thus, as mentioned earlier, this indicates that formal musical training cultivates a better performance in figure-ground, binaural integration, and temporal ordering skills.

Other studies have described the better performance of musicians in temporal processing. However, our results found no statistically significant difference between the groups, as both had good results in the DP test, reflecting an adequate performance and temporal ordering capacity. With a bigger sample, perhaps this result might be different.

Regarding the correlation of time of formal musical training with the test results described in Table 4, there was no correlation between the variables, showing that regardless of the length of musical training each participant had been through, the results did not differ. In our sample, the time of formal musical training ranged from 5 to 14 years, that is, the selected group had already devoted considerable time to learning music. Perhaps, therefore, their nervous systems had already been considerably shaped by this training, which may explain the lack of correlation. According to the literature, the time dedicated to music is an important factor in determining the plastic reorganization and neurological structural adaptations generated by musical learning [12,14-16]. As already described, musical learning provides great advantages to auditory and cognitive performance, leading to a better result when compared to people without musical training. 
Our study has shown that musical training provides better figure-ground with competing noise, binaural interaction, and temporal processing skills, which brings benefits not only for auditory performance, but also for linguistic skills. We infer that people with developed musical skills could potentially be better listeners, speakers, and communicators.

More studies involving larger samples and considering different variables such as type of instrument and method of music learning are encouraged.

\section{References}

1. Jerger J, Musiek F. Report of the Consensus Conference on the Diagnosis of Auditory Processing Disorders in School-Age Children. J Am Acad Audiol, 2000; 11(9): 467-74.

2. Terto SSM, Lemos SMA. Aspectos temporais auditivos: produção de conhecimento em quatro periódicos nacionais. Rev CEFAC, 2011; 13(5): 926-36.

3. Andrade NA, Gil D, Iorio MCM. Benchmarks for the dichotic sentence identification test in Brazilian Portuguese for ear and age. Braz J Otorhinolaryngol, 2015; 81(5): 459-65.

4. American Speech-Language-Hearing Association (ASHA). Central auditory processing disorders: The role of the audiologist (position statement). 2005. Available from <http://www.asha.org/policy $>$.

5. Talamini F, Altoè G, Carretti B, Grassi M. Musicians have better memory than non-musicians: a meta-analysis. PLoS One, 2017; 12(10): 1-21.

6. Baeck, E. The neural networks of music. Eur J Neurol, 2002; 9(5): 449-56.

7. Proverbio AM, Attardo L, Cozzi M, Zani A. The effect of musical practice on gesture/sound pairing. Front Psychol, 2015; 6: 376.

8. Cohen MA, Evans KK, Horowitz TS, Wolfe JM. Auditory and visual memory in musicians and non musicians. Psych Bull Rev, 2011; 18(3): 586-91.

9. Yates KM, Morre DR, Amitay S, Barry, JG. Sensitivity to melody, rhythm, and beat in supporting speech-in-noise perception in young adults. Ear Hear, 2019; 40: 358-67.

10. Eugênio ML, Escalda J, Lemos SMA. Desenvolvimento cognitivo, auditivo e linguístico em crianças expostas à música: produção de conhecimento nacional e internacional. Rev CEFAC, 2012; 14(5): 992-1003.

11. Rajendran VG, Teki S, Schnupp JWH. Temporal processing in audition: insights from music. Neurosci, 2018; 389: 4-18.

12. Engel AC, Bueno CD, Sleifer P. Treinamento musical e habilidades do processamento auditivo em crianças: revisão sistemática. Audiol Commun Res, 2019; 24(6): 1-8.

13. Moyeda IXG. Influencia de un entrenamiento em discriminación de estímulos tonales en la conciencia fonológica de niños pre escolares. Estudio piloto. Rev Iberoam Investig Desarro Educ, 2017; 8(15): 529-47.

14. Casarotto FD, Vargas LS, Mello-Carpes PB. Música e seus efeitos sobre o cérebro: uma abordagem da neurociência junto a escolares. Revista ELO-Diálogos em Extensão, 2017; 6(2): 55-60.

15. Prestes ZR, Tunes E, Pederiva PLM, Terci C. A emergência da reação estética da criança na atividade musical. Fractal Rev Psicol, 2018; 30(1): 46-57.

16. Habibi A, Cahn BR, Damasio A, Damasio H. Neural correlates of accelerated auditory processing in children engaged in music training. Dev Cogn Neurosci, 2016; 21(5): 1-14.

17. Madsen SMK, Whiteford KL, Oxenham AJ. Musicians do not benefit from differences in fundamental frequency when listening to speech in competing speech backgrounds. Scientific Reports, 2017; 7(1): 1-9.

ournal of Hearing Science · 2021 Vol. 11 · No. 3

\section{Conclusions}

After analyzing the results of this study, we conclude that individuals with formal musical training show better auditory attention skills, such as better ability to understand speech in a noisy environment, binaural interaction, and temporal processing. Thus, musical learning and practice contribute to developing good auditory skills, resulting in better communication and linguistic performance compared to individuals without previous musical learning.

18. Kraus N, Strait DL, Slater J, O'Connell S. Music training relates to the development of neural mechanisms of selective auditory attention. Devel Cog Neurosci, 2015; 12: 94-104.

19. Slater J, Kraus N, Carr KW, Tierney A, Azem A, Ashley R. Speechin-noise perception is linked to rhythm production skills in adult percussionists and non-musicians. Lang Cogn Neurosci, 2018; 33(6): 710-17.

20. Boéchat EM. Sistema auditivo nervoso central: plasticidade e desenvolvimento. In: Boéchat EM, Menezes PL, Couto CM, Frizzo ACF, Scharlach RC, Anastásio ART (eds), Tratado de Audiologia, Rio de Janeiro, Santos, 2015, pp.15-20.

21. Martins QP, Faccin VA, Brückmann M, Gil D, Garcia MV. Masking Level Difference em escolares: análise ambiental. CoDAS, 2018; 30(3): 1-7.

22. Wilson RH, Moncrieff DW, Townsend EA, Pillion AL. Development of a 500-Hz masking-level difference protocol for clinic use. J Am Acad Audiol, 2003; 14(1): 1-8.

22. Mendes SC, Branco-Barreiro FCA, Frota S. Limiar diferencial de mascaramento: valores de referência em adultos. Audiol Commun Res, 2017; 22: 1-5.

24. Pereira LD, Schochat E. Testes auditivos comportamentais para avaliação do processamento auditivo central. São Paulo: Pró-Fono; 2011.

25. Araújo NSS, Ruiz ACP, Pereira LD. SSW - análise qualitativa dos erros: inventário de atendimento de 2005. Rev CEFAC, 2009; 11(1): 44-51.

26. Tedesco MLF. Audiometria verbal: teste dicótico consoante-vogal em escolares de 7 a 12 anos de idade [thesis]. São Paulo: Universidade Federal de São Paulo; 1995.

27. Corazza MCA. Avaliação do Processamento Auditivo Central em adultos: testes de padrões tonais auditivos de freqüência e teste de padrões tonais auditivos de duração [thesis]. São Paulo: Universidade Federal de São Paulo; 1998.

28. Gicov RA, Tordin GC, Santos TMM, Branco-Barreiro FCA. Limiar Diferencial de Mascaramento em Crianças de Sete a Oito Anos. Rev Equilíbrio Corporal Saúde, 2015; 7(1): 17-20.

29. Bartz DW, Laux CN, Peruch CV, Ferreira MIDC, Machado MS, Ribas LP. Relação entre os achados do teste masking level difference e do reflexo acústico em crianças com transtorno fonológico. Rev CEFAC, 2015; 17(5): 1499-508.

30. Carvallo RMM. Auditory process: basic audiological evaluation. In: Pereira LD, Schochat E. Processamento auditivo central: manual de avaliação. São Paulo: Lovise; 1997, 27-35.

31. Esteves MCBN, Dell'Aringa AHB, Arruda GV, Dell'Aringa AR, Nardi JC. Brainstem evoked response audiometry in normal hearing subjects. Rev Bras Otorrinolaringol, 2009; 75(3): 420-25.

32. Santiago JM, Luiz CBL, Garcia M, Gil D. Masking level difference and electrophysiological evaluation in adults with normal hearing. Int Arch Otorhinolaryngol, 2020; 24(4): 399-406. 